\title{
VIOLÊNCIA CONTRA A MULHER: CONSEQUÊNCIAS DA PERSPECTIVA DE GÊNERO PARA AS POLÍTICAS DE SEGURANÇA PÚBLICA ${ }^{1}$
}

\section{DOMESTIC VIOLENCE AGAINST WOMEN: OUTCOMES OF GENDER PERSPECTIVE ON POLICING}

\author{
Thiago André Pierobom de Ávila \\ Ministério Público do Distrito Federal e Territórios (Brasília, DF, Brasil)
}

Recebimento: 18 abr. 2017

Aceitação: 24 jul. 2017

\begin{abstract}
Como citar este artigo / How to cite this article (informe a data atual de acesso / inform the current date of access):
ÁVILA, Thiago André Pierobom de. Violência contra a mulher: consequências da perspectiva de gênero para as políticas de segurança pública. Revista da Faculdade de Direito UFPR, Curitiba, PR, Brasil, v. 62, n. 3, p. 103-132, set./dez. 2017. ISSN 2236-7284. Disponível em: <http://revistas.ufpr.br/direito/article/view/51841>. Acesso em: 21 dez. 2017. DOI: http://dx.doi.org/10.5380/rfdufpr.v62i3.51841.
\end{abstract}

\section{RESUMO}

A Lei Maria da Penha promoveu um acréscimo significativo na demanda de atuação policial. Estudos têm demonstrado o caráter cíclico da violência doméstica, decorrente da dificuldade de rompimento de relações afetivas marcadas pela violência, com a resistência em denunciar e a tendência de reatar o relacionamento, bem como o caráter potencialmente letal na evolução deste ciclo de violência. Tais características das relações de gênero devem ser incorporadas nas estratégias político-criminais de atuação policial, trazendo como consequências: (1) a especial atenção à não prática de atos de revitimização durante as interações com a mulher; (2) a incorporação de novas estratégias de investigação criminal que não se fundamentem, exclusivamente, na palavra da vítima, diante do elevado risco de eventual não cooperação posterior da mulher com a persecução penal; e (3) a incorporação de estratégias político-criminais de monitoramento de casos de risco e de integração em rede para a prevenção da reiteração da violência. A realização de reformas nas instituições policiais a partir desse paradigma hermenêutico de gênero pode permitir substancial elevação na concretização do direito fundamental à segurança das mulheres.

\section{PALAVRAS-CHAVE}

Atuação policial. Política criminal. Perspectiva de gênero. Ciclo de violência. Proteção.

\begin{abstract}
The Maria da Penha Law promoted a significant impact on policing. Studies evidence the cyclic character of domestic violence, related to the obstacles to break intimate relationships marked by violence, with a reluctance to denounce the violence and the tendency to re-engage the relationship, as well as the potential lethality in the evolution of this cycle of violence. These characteristics of gender relations must be incorporated on policing policies, with: (1) the special attention to not produce revictimization during the interaction with women; (2) the incorporation of new strategies of

\footnotetext{
${ }^{1} \mathrm{O}$ presente artigo é fruto de pesquisa de pós-doutorado em criminologia na Monash University, Austrália. O autor agradece às Professoras Jude McCulloch, JaneMaree Maher, Kate Fitz-Gibbon e Jasmine McGowan pelas contribuições ao presente texto [N. do A.].
} 
criminal investigation that do not rely exclusively in the women's testimony, due to the high risk of victim's noncooperation to the criminal procedure; and (3) the incorporation of policies of monitoring high risk cases and the network integration of police in order to reduce the cyclic violence. The implementation of reforms on law enforcement agencies, guided by this gender hermeneutic paradigm, may allow a substantial elevation of the effectiveness of women's fundamental right to security.

\section{KEYWORDS}

Policing. Criminal policies. Gender perspective. Cycle of violence. Protection.

\section{INTRODUÇÃO}

Após o advento da Lei Maria da Penha (LMP), o enfrentamento à violência doméstica contra a mulher passou a demandar uma atuação intensa dos órgãos policiais e do sistema de justiça. Antes da LMP, havia uma tolerância institucional à violência contra a mulher, cristalizada no sistema do juizado especial criminal, que primava pela conciliação e não processamento dos casos (CAMPOS; CARVALHO, 2006). A mudança normativa tem passado por uma (gradual e lenta) incorporação de um novo paradigma hermenêutico de igualdade, respeito integral às mulheres e de não tolerância à violência na esfera privada. Esse movimento, todavia, oscila com reações de resistência à aplicação da lei (CAMPOS, 2017; PASINATO, 2015).

A persistência da violência doméstica contra a mulher no contexto brasileiro demanda uma reflexão que vai além da dimensão repressiva, exigindo a compreensão da intervenção estatal como política pública integral. Apesar das limitações do sistema policial, este ainda é uma porta de entrada relevante para as notícias de violência doméstica. Nesse contexto, o presente artigo propõe uma discussão sobre as consequências da incorporação do paradigma hermenêutico das relações de gênero para as políticas de segurança pública relacionadas à atuação policial. Para tanto, será feito breve retrato dos estudos relacionados à fenomenologia da violência doméstica e das características específicas dessa modalidade de criminalidade, marcada pelo caráter cíclico, pela paradoxal relação afetiva entre vítima e agressor e pelos valores sexistas que são interiorizados por vítima e agressor e que normalizam tal violência. Após, o estudo avançará na análise de três consequências políticocriminais para a atuação policial em tema de violência doméstica que emergem da incorporação da perspectiva de gênero, relacionadas à relevância da não revitimização para a efetividade da intervenção policial, à necessária preparação para a posterior não colaboração da vítima e à integração da atividade de investigação criminal com a prevenção, mediante a articulação do trabalho em rede e multidisciplinar. 
Essa análise leva em consideração estudos recentes sobre a aplicação da Lei Maria da Penha (BRASIL, 2017; CAMPOS, 2017; CARNEIRO, 2017; CARVALHO; OLIVEIRA, 2016; DINIZ; GUMIERI, 2016; DISTRITO FEDERAL, 2017; GOMES, 2014; PASINATO, 2015; WAISELFISZ, 2015) e documentos de orientação da atuação policial (BRASIL, 2016; ONU MULHERES, 2016), que permitem problematizar a atuação policial tradicional. Parte das informações contidas no texto é fruto da experiência profissional do autor como membro do Ministério Público (seu local de fala), com atuação na fiscalização de políticas públicas de promoção de direitos das mulheres.

Considerando a posição central das polícias como porta de entrada do sistema de justiça, espera-se que o presente artigo represente uma contribuição sobre os fundamentos teóricos da intervenção policial à luz do paradigma hermenêutico das relações de gênero e um fomento às experiências inovadoras de políticas públicas de segurança à mulher, de forma a promover mudanças para a qualificação dos serviços prestados às mulheres em situação de violência.

\section{O CARÁTER CÍCLICO E POTENCIALMENTE LETAL DA VIOLÊNCIA DOMÉSTICA}

No Brasil, 4.762 mulheres foram assassinadas em 2013, uma proporção de 4,8 mortes por 100.000 habitantes. Esse dado cresceu 21\% de 2003 a 2013. 50,3\% dessas mortes ocorrem em contexto de violência familiar, sendo que especificamente 33,2\% são praticadas pelo companheiro (atual ou passado) (WAISELFISZ, 2015). Enquanto na Austrália morre uma mulher por semana em contexto de violência praticada pelo companheiro (CUSSEN; BRYANT, 2015), e já se considera que essa taxa gera uma “urgência nacional” (OUR WATCH; ANROWS; VICHEALTH, 2015), no Brasil há alarmantes quatro mortes por dia praticadas pelo companheiro, em um total de 13 mortes femininas por dia (WAISELFISZ, 2015). Algumas capitais brasileiras possuem taxas proporcionais ainda mais epidêmicas de violência contra a mulher, como Vitória/ES (11,8 mortes/100.000 habitantes) ou Maceió (10,7 mortes/100.000 habitantes). Esses números fazem do Brasil o quinto país do mundo em taxas proporcionais de assassinatos de mulheres (WAISELFISZ, 2015).

Tais cifras estão associadas com uma quantidade difusa e diária de violência contra a mulher, fruto de uma cultura patriarcal que normaliza a violência disciplinar contra o gênero feminino (cf. BANDEIRA; THURLER, 2009). Com efeito, em 2014 ocorreram 47.646 estupros de mulheres no Brasil, uma média de um estupro a cada 11 minutos (FÓRUM BRASILEIRO DE SEGURANÇA PÚBLICA, 2015).

Os registros policiais de violência contra a mulher são alarmantes. Em Brasília, houve 4.258 casos de violência doméstica registrados em 2008 e 12.837 casos em 2016; ou seja, os atendimentos 
triplicaram ao longo de nove anos (DISTRITO FEDERAL, 2017). A expectativa é que tais números continuem a crescer, já que há uma quantidade enorme de casos que ocorrem e não são reportados (cifras ocultas).

Esse cenário de enfrentamento da violência doméstica contra a mulher tem demandado um esforço intenso e crescente das forças policiais. Com efeito, a LMP introduziu diversas inovações na atuação policial, como a colheita do pedido de medidas protetivas de urgência, as diligências de proteção indicadas no art. 11 da lei e um novo paradigma de atuação obrigatória ante os casos de lesão corporal, que anteriormente não eram registrados sem a autorização da vítima.

Todavia, a intervenção em crimes de violência doméstica contra a mulher é absolutamente distinta de outras formas de criminalidade, em que não há, usualmente, relações continuadas entre agressor e vítima, nem uma relação de poder que prende a vítima na relação violenta. Portanto, a atuação policial precisa compreender a complexidade das relações de gênero para ser efetiva no enfrentamento dessa modalidade criminal.

A violência doméstica contra a mulher deve ser vista como decorrente de uma estrutura patriarcal que historicamente legitimou (e ainda legitima) diversas violências (BANDEIRA; THURLER, 2009). Essa estrutura, interiorizada por homens e mulheres, impõe aos homens um papel de exercício de poder, provisão, manutenção da ordem e de agressividade para resolução de conflitos, e às mulheres um papel de submissão, cuidado e delicadeza; quando a mulher desafia essa ordem e reage, ela é pré-julgada e submetida a diversos mecanismos disciplinares, muitos deles interiorizados pela própria vítima. A normalidade dessa violência acaba por invisibilizá-la. Mesmo quando a mulher reage, nunca se está diante de uma relação efetivamente entre iguais (MACHADO, 2009). Normalmente a mulher fica presa num ciclo de violência, agravado pelas expectativas de papéis de cuidado e fidelidade pela mulher e por um duplo vínculo com o autor da agressão, que ao mesmo tempo a agride, mas em outros contextos possui um valor afetivo e aparentemente é seu protetor (ANGELIM, 2009).

Por permanecerem presas em uma relação marcada pela violência, é usual que quando as vítimas registrem ocorrências policiais, esta não seja a primeira vez que tenham sofrido uma violência doméstica. É também usual que a vítima, em algum momento no curso da investigação criminal ou ação penal, venha a se reconciliar com o agressor e deixar de colaborar com a persecução, mas, diante do caráter cíclico da violência, há uma elevada probabilidade de que volte a sofrer outros atos de violência num futuro próximo, que pode culminar numa violência potencialmente letal. Há uma resistência pelas vítimas para registrarem ocorrência policial, por fatores como medo, culpa, vergonha, dependência econômica ou emocional em relação ao agressor. Quando as vítimas registram 
ocorrência, usualmente elas estão indecisas se este é mesmo o melhor caminho, e muitas vezes se culpabilizam pela violência sofrida (PASINATO, 2012).

Esse quadro foi descrito por Walker (1979) como sendo o ciclo da violência doméstica, que gera um previsível risco de reiteração da violência em médio prazo. Inúmeros estudos têm demonstrado que a violência doméstica não é apenas um episódio isolado, é um contínuo de comportamentos de controle coercitivo e abusivo. Pesquisa do DataSenado (2005) documentou que $50 \%$ das mulheres entrevistadas que sofreram violência doméstica informaram que foram agredidas mais de uma vez. Pesquisa da Fundação Perseu Abramo (2011) indicou que uma em cada cinco mulheres reconhece já ter sido vítima de alguma forma de violência doméstica e, dos homens que reconheceram que já praticaram algum ato de violência doméstica, 50\% reconheceram que agrediram mais de uma vez. Pesquisa do DataSenado (2011) documentou que 32\% das mulheres entrevistadas que afirmaram que sofreram violência doméstica continuam convivendo com o agressor, das quais $18 \%$ indicaram que ainda estavam sofrendo a violência, sendo que $20 \%$ delas informou que a violência era diária e 40\% que era episódica. Outra pesquisa realizada com 10.000 mulheres na região Nordeste documentou que $27 \%$ das entrevistadas já sofreram ao menos um ato de violência doméstica em sua vida, sendo que $11,9 \%$ do total teriam sofrido um ato de violência doméstica no último ano (CARVALHO; OLIVEIRA, 2016).

A maioria dessas mulheres tem dificuldades em romper as relações violentas. Pesquisa do DataSenado (2013) documentou as principais causas para as mulheres não denunciarem a violência, com o seguinte percentual:

- $\quad$ Medo do agressor - $74 \%$

- Dependência financeira - 34\%

- Preocupação com a criação dos filhos - 34\%

- Vergonha da agressão - $26 \%$

- Não existir punição - 23\%

- Acreditar que seria a última vez - 22\%

- Não conhecer seus direitos - 19\%

- Outros motivos - $2 \%$

Estudos sugerem que cerca de $41 \%$ dos agressores voltam a praticar violência contra as vítimas no período de até 30 meses (KLEIN, 2009), indicando que o risco de reiteração da conduta pelo agressor é significativo em casos de violência doméstica. O potencial letal na reiteração da violência doméstica também é essencial, já que 50\% das mortes de mulheres ocorrem em contexto de violência familiar - especificamente, 33\% em contexto de violência praticada por parceiro íntimo (WAISELFISZ, 2015). Pesquisas internacionais indicam que a maioria das mortes de mulheres 
ocorrem em contexto de relacionamento marcado por violências anteriores (CAMPBELL et al., 2003). Ainda que o ciclo da violência não seja um padrão único e uniforme de manifestação da violência doméstica, é padrão recorrente e usual.

Quando as instituições que intervêm na situação de violência doméstica falham em compreender essas características essenciais desse tipo de criminalidade, elas podem perder a confiança da vítima, o que fará com que ela não apenas deixe de colaborar com o processo atual, mas, o que é mais grave, deixe de relatar um futuro (e previsível) novo ato de violência, impedindo o rompimento do ciclo da violência.

Portanto, a incorporação do paradigma hermenêutico de gênero preconizado pelo art. $4^{\circ}$ da LMP no âmbito da atuação policial permite formular, ao menos, três reflexões: (i) como a vítima usualmente está relutante em registrar a ocorrência policial, deve haver adequado acolhimento, pautado na sua não culpabilização pela violência sofrida, sob pena de se perder definitivamente sua colaboração; (ii) a investigação criminal deve partir da perspectiva de que, em algum momento, há uma elevada probabilidade de a vítima deixar de colaborar com as instituições de persecução criminal, o que não significa que o problema tenha sido resolvido (ao contrário, pode ser uma indicação de risco acentuado); (iii) diante do caráter cíclico da violência, a finalidade da intervenção policial deve ir além da investigação criminal e incorporar aspectos de prevenção da reiteração da conduta. Vejamos cada um desses aspectos.

\section{PROBLEMAS RELACIONADOS À REVITIMIZAÇÃO NO ÂMBITO POLICIAL}

Analisaremos adiante alguns dos vícios de atuação mais usuais no âmbito da atividade policial, objeto específico deste estudo. Grande parte do conhecimento para afirmar quanto à existência de tais vícios decorre da atuação profissional deste autor como Promotor de Justiça, coordenador de órgão responsável pela fiscalização das políticas públicas de promoção dos direitos das mulheres, bem como de controle externo da atividade policial relacionada à violência doméstica contra a mulher ${ }^{2}$.

Há que se registrar que inúmeros policiais têm se sensibilizado para o tema e avançado no aperfeiçoamento institucional da Polícia, especialmente, mas não apenas, no âmbito das delegacias

\footnotetext{
2 Sobre o tema, há no âmbito do Núcleo de Gênero do MPDFT, o PA 08190.021245/14-71, instaurado em fevereiro de 2014, para fins de controle externo da atividade policial da Delegacia Especial de Atendimento à Mulher - DEAM, e o PA 08190.044436/13-57, instaurado em agosto de 2013, para acompanhar as notícias encaminhadas pela Central de Atendimento à Mulher, então “Ligue 180”, relativas ao tratamento dispensado às mulheres vítimas de violência doméstica e familiar no âmbito das delegacias de polícia do DF.
} 
de polícia especializadas. Todavia, diversos vícios persistem. Ressalte-se, ademais, que tais defeitos de atuação perpassam todas as instituições que lidam com o atendimento à violência doméstica, como o Ministério Público, Judiciário e Defensoria Pública, que igualmente exigem ações especializadas de sensibilização e treinamento no tema.

Entende-se por revitimização, em sentido amplo, toda nova violência decorrente de uma violência anterior; nessa perspectiva, a própria continuidade do ciclo de violência é uma revitimização (BUZAWA; BUZAWA; STARK, 2017, p. 187). Todavia, o uso da expressão está usualmente associado à vitimização secundária, ou seja, o fato de uma vítima de violência voltar a ter novas experiências de sofrimento psíquico na interação com as instituições que deveriam protegê-la, usualmente na forma de tratamento inadequado, insensível ou recriminatório (PATTERSON, 2011). Atualmente, a Lei n. 13.431/2017 define em seu art. 4\%, inciso IV, o conceito de "violência institucional, entendida como a praticada por instituição pública ou conveniada, inclusive quando gerar revitimização”. Este conceito pode ser estendido ao âmbito da violência doméstica e familiar contra a mulher.

Um dos atos de revitimização mais usuais é a desvalorização da gravidade dos fatos no momento do atendimento. Ocorre quando policiais procuram induzir a vítima a relevar os fatos, dissuadindo-a de registrar a ocorrência policial, de requerer medidas protetivas de urgência, ou ainda, adiante, estimulando-a a se retratar da representação (PASINATO, 2012). Pode, portanto, também se manifestar como um incentivo à desistência do processo ao invés de ser um incentivo à continuidade, à ruptura da tolerância à situação de violência.

Há ainda o questionamento da veracidade das declarações da vítima. Especialmente, mas não apenas, nos crimes contra a dignidade sexual, coloca-se em questionamento a palavra da mulher e se realiza seu julgamento moral para condicionar a credibilidade de seu depoimento (cf. ANDRADE, 1999; PATTERSON, 2011). Fora do contexto da violência sexual, dúvidas sobre interesses patrimoniais da vítima ou eventual “uso abusivo da lei” podem diminuir o valor dado à sua palavra (PASINATO, 2015). Outra manifestação é dar credibilidade à versão do agressor, no caso de lesões recíprocas, mesmo quando desconectadas das evidências de lesões defensivas pela vítima, seu estado de aflição e desproteção, ou ainda padrões anteriores de comportamentos coercitivos ou intimidatórios. O cúmulo dessa perspectiva seria autuar a própria mulher como autora das agressões, ou se deferir (no âmbito do sistema judicial) medidas protetivas recíprocas, quando em verdade a 
mulher é a vítima da situação de violência doméstica ${ }^{3}$. Esse vício ocorre por se perder de perspectiva o caráter contínuo da violência doméstica, ou seja, por se realizar a investigação exclusivamente do episódio que demanda a intervenção policial, e não o contexto de violência doméstica.

Outra forma de revitimização, muitas vezes disfarçada de tentativa de apoio, é a recriminação moral pela continuidade da relação. Ocorre quando se culpabiliza a mulher por não ter rompido a relação violenta, desconhecendo toda a complexidade subjacente ao papel identitário que a cultura sexista atribui aos relacionamentos afetivos na vida das mulheres ${ }^{4}$. O “dispositivo amoroso" é interiorizado pelas mulheres e lhes impõe, a pretexto do "verdadeiro amor", a ideia de autossacrifício e submissão (NAVARRO-SWAIN, 2008). Normalmente é expresso no questionamento “Mas por que você ainda está com ele?” ou ainda na recriminação quando a mulher retoma o relacionamento afetivo após um registro de ocorrência e pede o arquivamento do processo. Pode até ocorrer num contexto de supostas boas intenções, para estimular a ruptura do relacionamento violento, mas se o tema é colocado de forma recriminatória, ou que a vítima se sinta recriminada, terá o efeito de inibir futuras demandas daquela mulher à instituição policial. Em vez de recriminar é necessário acolher, compreender as limitações em que a mulher se encontra, realizar um estímulo positivo para que ela dê o passo que é possível de ser dado naquele momento, e deixar a porta aberta para que ela sinta que possui liberdade de retornar em caso de reiteração da conduta.

Mais uma forma de revitimização é a discriminação institucional, que ocorre quando instituições públicas replicam estereótipos de discriminação, ou seja, quando há intersecção do gênero com outros marcadores de discriminação, como raça, classe social, idade, orientação sexual, religião, condição de pessoa deficiente. A experiência de ser mulher não é única; além da discriminação de gênero é igualmente possível que outros fatores venham agravar ainda mais o acesso às políticas públicas de proteção. O chamado racismo institucional representa o fracasso coletivo de organizações em prestar serviços adequados às pessoas de grupos vulneráveis à discriminação (cor, cultura, origem racial ou étnica), por não evitar que se repliquem dentro de suas instituições os estereótipos que vigem na sociedade, diante da falta de atenção e ignorância sobre a discriminação (cf. SAMPAIO, 2003). Estudos têm documentado a má prestação de serviços públicos à população negra, especialmente na

\footnotetext{
${ }^{3}$ Victoria (2016, p. 18) indica diversas pesquisas em que muitas vezes, quando mulheres são autuadas por violência doméstica, elas, em verdade, estavam reagindo defensivamente a um contexto de agressões, havendo uma inversão de posições. Diversos países têm trabalhado com o conceito de “agressor primário” para permitir que, em casos de agressões recíprocas, se leve em consideração o histórico de comportamento controlador e abusivo de um dos parceiros (usualmente o homem), a fim de se perspectivar o episódio dentro do contexto de violência (cf. HIRSCHEL; BUZAWA, 2012).

${ }^{4}$ Em cursos de formação ministrados pelo autor a policiais, em diversas oportunidades se percebeu incompreensão quanto a esse tópico específico, inclusive de relatos de policiais que “dão uma dura” na mulher, para “ajudar” a sair da situação de violência.
} 
área de saúde (KALKMANN et al., 2007). Os mecanismos de discriminação racial operam ao nível do inconsciente e induzem a uma representação de menor relevância do sujeito estigmatizado. A Lei n. 13.431/2017 prevê em seu art. 4 , inciso II, alínea “a” c/c inciso IV, que a discriminação praticada por instituições públicas é uma forma de violência institucional. Este conceito de discriminação institucional foi igualmente acolhido pelo Estatuto da Igualdade Racial (Lei n. 12.288/2010, art. 4º IV). Apesar de o foco dessas leis ser parcialmente distinto, o conceito de discriminação institucional se aplica perfeitamente no âmbito mais amplo da violência contra a mulher, manifestando-se especificamente no âmbito da atividade policial como o maior risco de abordagem policial mais incisiva a agressores negros, tidos como "elementos suspeitos" e potencialmente mais perigosos (RAMOS; MUSUMECI, 2005), bem como em se subestimar a importância de atendimento de mulheres negras (cf. CARNEIRO, 2017).

Com efeito, estatísticas indicam que 66,7\% das mulheres assassinadas são negras (WAISELFISZ, 2015), apesar de os negros corresponderem a 51\% da população (INSTITUTO BRASILEIRO DE GEOGRAFIA E ESTATÍSTICA, 2010). De 2003 a 2013, a taxa percentual de assassinatos de mulheres brancas diminuiu 9,8\%, enquanto essa taxa aumentou 54,2\% para as mulheres negras (WAISELFISZ, 2015). Outros estudos indicam que fatores macrossociais, como desigualdade social e desagregação das relações sociais, podem elevar as taxas de mortes de mulheres (GOMES, 2014).

Essa discriminação institucional pode se manifestar, por exemplo, na falta de paciência ou em comentários discriminatórios durante um atendimento a uma mulher de baixo nível socioeconômico, ou com problemas mentais, que eventualmente tenha dificuldades de se expressar ou de detalhar os episódios de violência, ou uma mulher lésbica.

Todas essas manifestações de revitimização são fruto de uma discriminação institucional, a repetição dentro de instituições públicas, por seus agentes, de estereótipos de discriminação de gênero, raça, classe social ou outros fatores. O enfrentamento do problema passa, portanto, por uma mudança da cultura organizacional ante o tema das relações de gênero e, especificamente, da violência doméstica contra a mulher.

Finalmente, além desses problemas específicos da violência doméstica ou suas intersecções com outros marcadores de discriminação, há a usual reclamação de falta de atuação policial. A CPMI da violência doméstica documentou o sucateamento das diversas Delegacias Especializadas de Atendimento à Mulher (DEAM) no Brasil, exceção feita à DEAM do Distrito Federal (BRASIL, 2013, p. 48-51). O quadro é de ausência de servidores, falta de estrutura adequada, falta de capacitação e a não aplicação integral de dispositivos da Lei Maria da Penha. Por exemplo, a CPMI 
documentou a prática, em diversas delegacias de polícia, de não se realizar a oitiva da vítima no momento do registro da ocorrência policial, mas se agendar para data futura. Essa prática gera o risco de eventual desistência da mulher neste interregno, bem como cria um obstáculo ao acesso à justiça, já que a oitiva da vítima é um pré-requisito para a formulação do pedido de medidas protetivas de urgência. Além dessa prática, constatou-se demora na conclusão das investigações, com muitos procedimentos parados, sem andamento há diversos anos (como no caso de Manaus).

Apesar de o estudo da CPMI datar de 2012 e ser possível que alguns desses serviços tenham melhorado, o retorno dado por diversos profissionais tem indicado a persistência de problemas estruturais na atuação policial Brasil afora, apesar de algumas experiências positivas em capitais de estados $^{5}$.

Pesquisa de Diniz e Gumieri (2016) indicou que cerca de 48\% dos indeferimentos de requerimentos de medidas protetivas de urgência no Distrito Federal ocorrem pela ausência de informações detalhadas sobre o caso, indicando, por um lado, uma provável resistência do sistema judicial na aplicação da LMP, mas, por outro, uma possível deficiência do sistema policial em instruir adequadamente o requerimento de medidas protetivas de urgência.

Esse quadro é reflexo de uma falência generalizada da investigação criminal no Brasil. Com efeito, estudos têm indicado o arquivamento de boletins de ocorrência sem a instauração de inquéritos policiais, a demora na conclusão de investigações instauradas e o baixo nível de efetividade na resolução de casos mais complexos (ADORNO; PASINATO, 2008; MISSE, 2010).

Segundo informações disponibilizadas pela Central do Ligue 180, da Secretaria de Políticas para as Mulheres, as principais reclamações relacionadas aos serviços da rede de atendimentos às mulheres são os seguintes:

\footnotetext{
${ }^{5}$ Este autor integra a Comissão Nacional Permanente de Promotores de Justiça de Violência Doméstica contra a Mulher (Copevid), na qual recebe o feedback da situação de diversos estados brasileiros.
} 
Tabela 1: Informações da Central Ligue 180 sobre as reclamações de serviços públicos de atendimento à mulher.

\begin{tabular}{|c|c|c|c|c|}
\hline SERVIÇO PÚBLICO & Ano 2015 & Ano 2016 & Total & Percentual \\
\hline Departamento de Polícia & 577 & 987 & 1.564 & $21,2 \%$ \\
\hline Delegacia da Mulher & 431 & 620 & 1.051 & $14,2 \%$ \\
\hline 190 & 343 & 632 & 975 & $13,2 \%$ \\
\hline Defensoria Pública & 157 & 202 & 359 & $4,9 \%$ \\
\hline Fórum & 139 & 186 & 325 & $4,4 \%$ \\
\hline Centro de Referência & 125 & 123 & 248 & $3,3 \%$ \\
\hline Central de Atendimento à Mulher & 121 & 111 & 232 & $3,1 \%$ \\
\hline Ministério Público & 85 & 106 & 191 & $2,6 \%$ \\
\hline $\begin{array}{l}\text { Juizado Especial de Violência Doméstica e } \\
\text { Familiar }\end{array}$ & 32 & 39 & 71 & $1,0 \%$ \\
\hline Corregedoria & 16 & 43 & 59 & $0,8 \%$ \\
\hline Casa Abrigo & 17 & 23 & 40 & $0,5 \%$ \\
\hline Outros & 919 & 1,350 & 2.269 & $30,8 \%$ \\
\hline TOTAL & 2.962 & 4.422 & 7.384 & $100 \%$ \\
\hline
\end{tabular}

Fonte: BRASIL, 2017.

Considerando que as reclamações relacionadas ao Disque 190 são ordinariamente relacionadas à atuação da Polícia Militar (demora ou omissão de atendimento após um chamado em flagrante delito ou emergência), verifica-se que quase a metade dos casos de reclamações de mulheres (48,6\%) são relacionados à atuação policial.

Especificamente com relação às reclamações relacionadas às delegacias de polícia (35,4\% dos casos), os motivos mais usuais das reclamações são os seguintes:

Tabela 2: Informações da Central Ligue 180 sobre os motivos das reclamações relacionadas às delegacias de polícia no atendimento à mulher.

\begin{tabular}{|c|c|c|c|c|}
\hline MOTIVO & Ano 2015 & Ano 2016 & Total & Percentual \\
\hline Maus Tratos & 152 & 246 & 398 & $15,7 \%$ \\
\hline Omissão & 124 & 266 & 390 & $15,3 \%$ \\
\hline $\begin{array}{l}\text { Recusa de Registro do Boletim de } \\
\text { Ocorrência }\end{array}$ & 124 & 229 & 353 & $13,9 \%$ \\
\hline Atendimento Inadequado & 117 & 166 & 283 & $11,1 \%$ \\
\hline $\begin{array}{l}\text { Falta de Providência Sobre o Boletim de } \\
\text { Ocorrência }\end{array}$ & 103 & 179 & 282 & $11,1 \%$ \\
\hline $\begin{array}{l}\text { Despreparo em Casos de Violência } \\
\text { Doméstica/Familiar }\end{array}$ & 108 & 170 & 278 & $10,9 \%$ \\
\hline Dificuldade de Acesso & 56 & 85 & 141 & $5,5 \%$ \\
\hline Infraestrutura Inadequada & 2 & 3 & 5 & $0,2 \%$ \\
\hline Outros & 134 & 275 & 409 & $16,3 \%$ \\
\hline TOTAL & 920 & 1.619 & 2.539 & $100 \%$ \\
\hline
\end{tabular}

Fonte: BRASIL, 2017.

Verifica-se que a causa de reclamação mais usual é a não atuação policial, decorrente de omissão, recusa de registro de BO, ou falta de providências sobre o BO (40,3\%). Conforme o 
conteúdo de diversas reclamações da atividade policial recebidas no MPDFT, há relatos de vítimas que ligaram para o Disque 190, mas a polícia não foi ao local, ou que esperaram demasiadamente na delegacia de polícia, a ponto de desistirem do atendimento ${ }^{6}$. Por outro lado, se somados os casos de maus tratos praticados por policiais, atendimento inadequado e despreparo na atuação (37,7\%), verifica-se que a segunda causa mais comum de reclamações de mulheres são as condutas ativas de revitimização. Há que se ressaltar que mesmo a omissão é uma forma de revitimização (por inação).

Essas informações do Ligue 180 colocam a atuação das polícias como área sensível à concretização do sistema de proteção às mulheres, ao menos na percepção das mulheres que são atendidas. Os problemas de omissão passam pela falta de estrutura, pela má gestão dos parcos recursos humanos e materiais disponíveis, mas sobretudo por um modelo de investigação criminal permeado por diversas falhas estruturais que travam sua possiblidade abstrata de efetividade. Com efeito, a investigação criminal no Brasil é desenvolvida dentro de um modelo cartorário, burocrático, segmentado no ciclo de prevenção/investigação, bacharelesco, que não valoriza as provas técnicas e não se articula com a rede de serviços e a comunidade para a construção de estratégias de prevenção criminal. Uma das poucas críticas possíveis à Lei Maria da Penha é exatamente a repristinação desse vetusto instrumento de investigação, o inquérito policial (PASINATO, 2010).

Em um ambiente ordinário de sobrecarga de trabalho, o não enfrentamento de uma cultura sexista de sub-representação da relevância da violência contra a mulher acaba forçando uma deriva para a inação policial diante da violência contra a mulher. A revitimização retira a predisposição de continuidade da colaboração da vítima com a persecução penal, e retira sua disposição em relatar novas formas de violência (BUZAWA; BUZAWA; STARK, 2017, p. 187; PASINATO, 2012; PATTERSON, 2011). Ademais, esses problemas de revitimização no âmbito policial comprometem a efetividade de toda a intervenção estatal, pois criam uma deslegitimidade para os demais serviços da rede pública, enfraquecendo sua capacidade de criar uma relação de confiança com a mulher. Urge construir novas práticas de atuação policial não revitimizantes, como estratégia não apenas de respeito de direitos fundamentais (o que já seria motivo suficiente), mas igualmente de eficiência na intervenção policial, na medida em que o acolhimento humanizado diminui a natural ambivalência da mulher em contexto de violência.

\footnotetext{
6 Ver documentação constante dos PAs do NG/MPDFT, suprarreferidos (PA 08190.021245/14-71 e PA 08190.044436/13-57).
} 


\section{PREPARAÇÃO PARA A AUSÊNCIA DE COLABORAÇÃO DA VÍTIMA}

Uma segunda consequência da perspectiva de gênero para a atuação policial consiste na previsibilidade de que um número significativo de vítimas provavelmente irá deixar de colaborar com a persecução criminal em algum momento. Isso não significa que o problema tenha sido resolvido, apenas que o ciclo da violência está na fase da reconciliação e que, se não houver uma adequada intervenção, é possível que ele volte a evoluir para episódios mais graves de violência. Portanto, responsabilizar o agressor por seus atos, apesar da ausência de colaboração da vítima, é um aspecto central da prevenção da reiteração de outras condutas violentas. Há um interesse público nessa responsabilização, que transcende a disponibilidade da vítima, pois o arquivamento do caso, sem qualquer intervenção efetiva na situação de violência, apenas reforçaria o risco de a violência reiterarse de forma agravada e reafirmaria um valor inaceitável de tolerância coletiva à violência contra a mulher ${ }^{7}$.

Assim, afora os problemas já citados de revitimização, ainda que a equipe policial esteja sensibilizada para a intervenção em casos de violência doméstica, é necessário pensar estratégias para se superar a previsível situação de ausência de colaboração da vítima. Estudos nos EUA indicam que em cerca de $60 \%$ dos casos de violência doméstica há pedido pela vítima de arquivamento do caso (BUZAWA; BUZAWA; STARK, 2017, p. 135).

Há duas situações jurídicas distintas para a ausência de colaboração da vítima: crimes de ação pública condicionada ou incondicionada. O crime de lesão corporal se procede mediante ação penal pública incondicionada, conforme decisão do $\mathrm{STF}^{8}$. Da mesma forma, inúmeras outras infrações penais usualmente praticadas em contexto de violência doméstica, como todas as contravenções penais (especialmente as vias de fato e a perturbação da tranquilidade), o dano em contexto de violência à pessoa ou grave ameaça, o cárcere privado e a desobediência à ordem de medida protetiva de urgência (com a polêmica sobre a tipicidade dessa última conduta) ${ }^{9}$.

Com relação ao crime de ameaça ainda há necessidade da autorização da vítima para a persecução penal, sendo admissível que ela voluntariamente (e de forma não induzida) se retrate da representação, aplicando-se o procedimento da audiência de ratificação prevista no art. 16 da LMP.

\footnotetext{
${ }^{7}$ Não estamos avançando aqui na discussão se a prisão é a única forma de resposta estatal à violência doméstica contra a mulher, ou se seria possível construir outras formas de responsabilização menos violentas e mais efetivas.

${ }^{8}$ STF, ADIN 4424, rel. Min. Marco Aurélio, Pleno, m.v., j. 09 fev. 2012, DJe 1 ago. 2014.

${ }^{9}$ Decisões recentes do STJ têm, equivocadamente, negado a tipicidade dessa conduta, ao argumento de que haveria outras sanções específicas e na legislação de regência, como decretar a prisão preventiva ou se impor multa cominatória, desconsiderando a necessidade de proteção imediata à mulher. Ver STJ, AgRg no REsp 1528271/DF, rel. Min. Jorge Mussi, 5 ${ }^{a}$ T., j. 13 out. 2015, DJe 21 out. 2015.
} 
Semelhantemente, para os delitos contra a honra, a ação penal será privada, o que significa que, além de manifestar sua vontade para o início da atuação policial, será necessário à vítima contratar advogado, ou contatar o serviço de assistência jurídica que deve ser prestado pelo Estado, para ela promover a persecução penal. À guisa de exemplo, no Distrito Federal, em 60\% dos processos há notícia de ameaça, em 58\% há notícia de crimes contra a honra, em 32\% há notícia de lesão corporal, e em 14\% há notícia de contravenção penal de vias de fato (DISTRITO FEDERAL, 2017) ${ }^{10}$. Isso significa que a maioria dos casos de violência doméstica notificados ainda está na esfera de disponibilidade da vítima.

A solução do problema da ausência de cooperação da vítima em relação aos crimes que ela possui disponibilidade (e mesmo dos que não possui, mas pela relevância de sua cooperação) passa por estratégias mais efetivas de apoio à vítima ao longo do processo, de forma a diminuir sua insatisfação com a resposta estatal e, assim, elevar sua cooperação (BRASIL, 2016, p. 31; BUZAWA; BUZAWA; STARK, 2017, p. 220).

Com relação aos casos de ação incondicionada, é necessário preparar a persecução penal para prosseguir com sucesso apesar da eventual ausência de colaboração da vítima. Isso não significa dizer que não seja possível o processamento criminal apenas com a palavra da vítima. Ao contrário, a jurisprudência pátria tem corretamente se inclinado pela valorização da palavra da vítima, especialmente quando não existem outras testemunhas (e usualmente não haverá no contexto doméstico ${ }^{11}$. Mas o risco de não colaboração posterior existe e é dever das instituições públicas estarem preparadas para esse cenário.

Para tanto, é essencial que a polícia tenha protocolos de investigação criminal que partam da premissa de que é possível adiante não ter a colaboração da vítima, e produza provas suficientes para se sustentar uma acusação nessa situação (EIGENBERG; KAPPELER; MCGUFFEE, 2012). Essa investigação deve avançar no recolhimento de declarações de terceiros, como a entrevista de vizinhos sobre os fatos (cf. exemplo da enquête de voisinage pela polícia francesa em ÁVILA, 2014), entrevista com parentes ou crianças do núcleo familiar, bem como a documentação de outras evidências materiais de violência. Também pode abranger o uso de câmeras de filmagem no momento do atendimento da ocorrência policial (as chamadas body-worn cameras - BWC), de forma que as declarações prestadas pela vítima e pelo agressor sejam imediatamente documentadas, com possível utilização em juízo (cf. exemplo dessa estratégia pela polícia inglesa em SUXBERGER, 2014). A

\footnotetext{
${ }^{10}$ É possível que em um processo haja notícia de mais de um crime.

${ }^{11}$ STJ, AgRg no AREsp 962.903/DF, rel. Min. Reynaldo Soares da Fonseca, 5a T., j. 15 set. 2016, DJe 23 set. 2016.
} 
comissão de enfrentamento à violência doméstica de Victoria (2016, p. 80), Austrália, igualmente reconheceu a relevância dessa metodologia investigativa e recomendou sua utilização. Incorporar ao processo as gravações das ligações feitas pela mulher ao serviço de emergência (190), para a chamada de intervenção policial, é outra boa estratégia.

Sobre o uso da BWC, White (2014) afirma que elas possuem o benefício de: elevar a transparência e legitimidade da atuação policial, evitando eventuais comportamentos ilícitos praticados por policiais, prevenir comportamentos ilícitos pelos cidadãos abordados, já que eles saberão que estão sendo filmados, e portanto haverá uma prova documental contra si em caso de desacato ou agressão ao policial, facilitação da apuração de eventuais reclamações relacionadas à atuação policial, bem como facilitação da comprovação do ilícito que demandou a intervenção policial, além de serem um instrumento útil na colaboração com o treinamento na atividade policial. Eventualmente, o depoimento da vítima poderia ser recolhido diretamente na cena do crime, evitandose que ela tenha que explicar a situação ao policial e posteriormente repetir suas declarações na delegacia de polícia. Por outro lado, o uso da BWC deve vir acompanhado da preocupação de se regulamentar a devida obtenção de autorização da vítima para realizar sua gravação, da informação ostensiva ao abordado, já na cena do crime, de que ele está sendo gravado e de que possui direito ao silêncio, de cautelas especiais relacionadas à violação da privacidade do cidadão (v.g., uma revista íntima), de ações adequadas de treinamento e de adequada manutenção do novo equipamento de trabalho (incluindo capacidade de armazenamento de dados). O direito da defesa de realizar a cross examination da vítima em juízo deve ser preservado. Especial atenção deve ser dada à impossibilidade de divulgação desse material, dado o caráter fortemente íntimo de seu conteúdo, e os riscos para a vítima relacionados à virtual impossibilidade de se retirar de circulação um conteúdo intrusivo que eventualmente venha ser disponibilizado na internet. Apesar de todas as ponderações, o uso de BWC para casos de violência doméstica contra a mulher é uma tendência mundial, com experiências nos EUA, Canadá, Reino Unido e Austrália (BUZAWA; BUZAWA; STARK, 2017, p. 221; SUXBERGER, 2014; VICTORIA, 2016, p. 80; WHITE, 2014).

Ainda que não haja a filmagem do atendimento na cena do crime, a intervenção ao chamado de ocorrência já deve envolver um nível elevado de atividade investigativa, como entrevistas com vizinhos ou testemunhas, documentação do estado anímico da vítima, agressor e eventuais crianças na cena do crime, o recolhimento oral das primeiras declarações da vítima sobre a dinâmica dos fatos ainda no local do crime, a análise criteriosa dos sinais de um contexto de violência doméstica no local do crime, como objetos quebrados, desordem, se possível já tirando fotografias no momento do atendimento (cf. rol de diligências que devem ser realizadas na intervenção de flagrante delito de 
violência doméstica em BRASIL, 2016, p. 51). É essencial que haja sensibilidade policial para recolher tais detalhes ainda na cena do crime, e usualmente essa intervenção será feita pela Polícia Militar. Peritos nem sempre terão condições de comparecer a todos os incidentes ordinários de violência doméstica. A investigação de casos de violência doméstica usualmente não é complexa, pois no momento de se acionar a intervenção policial a vítima já fornece as informações gerais do caso, bastando documentar as versões dos envolvidos, das possíveis testemunhas, e os vestígios materiais desse delito.

A efetividade destas estratégias de investigação passa por uma necessária reconstrução das tradicionais divisões de tarefas entre Polícia Civil e Militar. Isso porque quem usualmente atende in loco às chamadas de ocorrências policiais de todos os crimes, inclusive de violência doméstica, é a Polícia Militar. Na divisão tradicional de funções, a Polícia Militar não é formalmente responsável pela investigação criminal, que será conduzida pela Polícia Civil. Todavia, se a Polícia Militar não se perspectivar como corresponsável pelo sucesso da investigação criminal, uma parcela significativa de informação investigativa, consistente na documentação do momento de atendimento da ocorrência policial, será perdida. Essa segmentação da investigação criminal está ligada à cisão do ciclo investigativo no Brasil, que gera uma disfunção institucionalizada no processo investigativo e exigiria uma “revolução na arquitetura institucional da segurança pública” (SOARES; BALESTRERI, 2012). A cisão de atribuições entre Polícia Militar e Civil acaba retirando parte significativa do potencial de efetividade da intervenção investigativa imediata na cena do crime.

Em outros países, a documentação imediata do atendimento policial fica a cargo dos policiais que atendem à ocorrência, e apenas em situações de necessária investigação aprofundada o caso é referido a policiais “detetives”, que prosseguirão com a investigação (cf. VICTORIA, 2016, p. 70). No Brasil, usualmente se despreza as informações dos policiais militares que possuem a riqueza de detalhes do atendimento à ocorrência policial, e impõe-se um retrabalho desnecessário à Polícia Civil, que acaba tendo atuação meramente cartorária de documentação em vez de ser proativa na investigação dos delitos que necessitariam de maior aprofundamento.

Portanto, a necessária efetividade na investigação de crimes de violência doméstica contra a mulher exige uma participação ativa da Polícia Militar na produção de informações investigativas no momento da intervenção no chamado da ocorrência policial, pois se trata de atos de manutenção da ordem com reflexos diretos na atividade de investigação criminal (ÁVILA, 2016b, p. 207). É um erro afirmar que a Polícia Militar não possui atribuição investigativa no sistema brasileiro, pois ela é substancialmente responsável pela investigação preliminar à possibilidade de intervenção da Polícia Civil. Enquanto não se produz uma reforma estrutural na segurança pública, há que se pensar na 
concretização de um “princípio de cooperação das instituições de segurança pública” (ÁVILA, 2016a, p. 353) que já permita um maior protagonismo da Polícia Militar na cooperação para obtenção de informações legislativas no momento do atendimento da ocorrência policial.

Outra estratégia relevante, mas sistematicamente negligenciada no âmbito da Polícia Civil, é fotografar as lesões corporais, para se documentar as marcas do crime. Como argumentam Eigenberg, Kappeler e McGuffee (2012, p. 134): “esse é o tipo de prova que menos consome tempo e gastos para se coletar”. Em muitos casos as mulheres não são conduzidas pelos policiais ao IML, como determina o art. 11, inciso II, da LMP, perdendo-se a prova da materialidade das lesões. Em outras situações, a perda de colaboração da vítima ocorre no curso do atendimento policial, e muitas vezes ela deixa de atravessar a rua para ir da Delegacia de Polícia ao IML.

Vale ressaltar que tais estratégias de investigação criminal terão o benéfico efeito de aliviar a pressão sobre a vítima, de ter de cooperar com a justiça criminal em um momento futuro em que ela já atingiu seus objetivos de proteção e, portanto, a perspectiva punitiva não lhe confere muito sentido, apesar de sua relevância para a afirmação da intolerância social à violência doméstica (BUZAWA; BUZAWA; STARK, 2017, p. 220).

Finalmente, nos casos de elevado risco à vítima e histórico de dependência emocional para com o agressor ou de exposição ao risco de constrangimento para a retratação, é conveniente a realização da produção antecipada de provas. Para tanto, é essencial que as atuais regras de antecipação da prova (CPP, art. 156, inciso I e art. 225) sejam interpretadas à luz das diretrizes hermenêuticas da Lei Maria da Penha, que prevê expressamente em seu art. $4^{\circ}$ que "Na interpretação desta Lei, serão considerados os fins sociais a que ela se destina e, especialmente, as condições peculiares das mulheres em situação de violência doméstica e familiar”. A condição peculiar da mulher consiste exatamente nessa fragilidade à continuidade da relação violenta potencialmente letal ou ao risco de pressão para a ausência de colaboração, que exige que haja a documentação de suas declarações no momento atual do ciclo de violência, enquanto ainda há perspectiva de cooperação com as instituições de persecução penal. Isso exige uma agilidade em sua oitiva em juízo incompatível com a ordinária lentidão na conclusão da investigação criminal e nas fases preliminares do trâmite judicial. Trata-se de uma prova urgente e relevante, que não poderá existir em sua integralidade caso se aguarde o trâmite ordinário de alguns meses (na melhor das situações de uma delegacia de polícia e vara judicial não sobrecarregadas). 
Diversos países preveem expressamente essa modalidade de produção probatória no contexto de violência doméstica, como Portugal (Lei n. 112/2009, art. 33) ${ }^{12}$ e Itália (CPP italiano, art. 392, 1-bis, com a redação da Lei n. 212/2015) ${ }^{13}$, bem como há diretrizes internacionais para sua realização (BRASIL, 2016, p. 19, 65). Especificamente na legislação brasileira, a Lei n. 13.431/2017, art. 11, $\S 1^{\circ}$ (com início de vigência prevista para 04 de abril de 2018), estabelece a obrigatoriedade da produção antecipada de provas em casos de crimes sexuais contra crianças e adolescentes, ou de oitiva de crianças menores de sete anos de idade, bem como o caput da referida norma indica ser recomendável ("sempre que possível”) tal metodologia probatória em outros contextos de crimes contra crianças e adolescentes. O art. 21, inciso VI, da referida lei, corretamente alinhado com o sistema acusatório, indica que o procedimento desta oitiva se procede mediante ação cautelar ajuizada pelo Ministério Público (cf. CPC, art. 382 c/c CPP, art. $3^{\circ}$ ), e o art. 22 indica a relevância de coleta de outros meios de prova pela investigação criminal, além do depoimento da vítima.

É de todo conveniente que a legislação brasileira incorpore expressamente tais regras de produção antecipada de prova no âmbito da violência doméstica contra a mulher. Todavia, uma interpretação sistemática da novel legislação e atuais regras do CPP, em conjunto com a diretriz do art. $4^{\circ}$ da Lei Maria da Penha, permite a conclusão da admissibilidade da produção antecipada de provas em caso de risco de constrangimento à mulher em situação de violência doméstica ou ainda de risco de ela reatar o relacionamento, de forma a se perder a colaboração da vítima ao longo da persecução penal. Aplica-se essa diretriz especialmente às mulheres idosas, estrangeiras, mulher na iminência de mudar-se de residência para fugir da violência, ou ainda em situação de hipossuficiência econômica que eleve o risco de posterior não localização em juízo. Essa metodologia de proteção à mulher mediante a oitiva antecipada exige um elevado grau de articulação entre Polícia, Ministério Público e Poder Judiciário, já que necessitará de comunicação pela Polícia, ajuizamento da ação cautelar pelo MP, e a sensibilidade do Judiciário para acolher a medida cautelar. Portanto, essa articulação deve se materializar em protocolos interinstitucionais. A operabilidade da proposta exige,

\footnotetext{
12 Trata-se da lei que rege o "regime jurídico aplicável à prevenção da violência doméstica, à proteção e à assistência das suas vítimas”. Conferir: “Art. 33. Declarações para memória futura. 1 - O juiz, a requerimento da vítima ou do Ministério Público, pode proceder à inquirição daquela no decurso do inquérito, a fim de que o depoimento possa, se necessário, ser tomado em conta no julgamento. [...] 7 - A tomada de declarações nos termos dos números anteriores não prejudica a prestação de depoimento em audiência de julgamento, sempre que ela for possível e não puser em causa a saúde física ou psíquica de pessoa que o deva prestar".

${ }^{13}$ Cf. tradução nossa: "No procedimento para os delitos dos artigos 572 [...] do Código Penal [relativo ao crime de "maus tratos contra familiar ou convivente”], o Ministério Público, ou ainda por requerimento da ofendida ou do investigado, pode requerer que se realize o incidente probatório de produção de testemunho de pessoa menor, bem como de pessoa maior, ainda que fora das hipóteses previstas no $\S 1^{\circ}$. Em qualquer situação, quando a vítima estiver em situação de particular vulnerabilidade, o Ministério Público, por requerimento da ofendida ou do investigado, pode requerer que se realize o incidente probatório de produção de testemunho”.
} 
igualmente, a delimitação dos casos mais graves de risco de perda da colaboração da vítima, a ensejar a produção antecipada de provas. A atribuição de prioridade de tramitação aos casos de risco elevado pode ser um sucedâneo dessa estratégia.

Atualmente, algumas ferramentas se propõem a contribuir como guias de atuação para o aperfeiçoamento da investigação criminal, como as Diretrizes Nacionais de Investigação Criminal com Perspectiva de Gênero, documento produzido pela SPM, Copevid/GNDH e Senasp/MJ, em parceria com a União Europeia (BRASIL, 2016), bem como as Diretrizes Nacionais de Feminicídio, documento produzido em parceria com a ONU Mulheres (ONU MULHERES, 2016) ${ }^{14}$.

A consequência prática da não incorporação das estratégias investigativas de comprovação do contexto da violência é o incremento do risco de absolvição por insuficiência de provas caso eventualmente a vítima não coopere com a produção da prova em juízo. Há que se ter em mente, todavia, que é impossível assegurar efetividade integral na totalidade dos casos, e um percentual de absolvições é inevitável (certamente, muito menos do que se vê atualmente). A intervenção penal de viés punitivo possui um limite de atuação (PASINATO, 2015). Para além da punição, é necessário pensar em estratégias integradas de proteção.

\section{INTEGRAÇÃO ENTRE INVESTIGAÇÃO E PREVENÇÃO DA REITERAÇÃO DA VIOLENCIA}

Finalmente, a incorporação da perspectiva de gênero impõe a conclusão de que a polícia não pode estar limitada a apenas realizar a investigação de fatos já passados, para assegurar a adequada punição dos agressores. A atuação policial deve incorporar um conjunto articulado de estratégias político-criminais de proteção à mulher, de forma a concretizar seu direito fundamental à segurança pública $^{15}$.

Tratar adequadamente o episódio atual de violência doméstica também é prevenir um possível episódio futuro. A investigação criminal projeta-se para o passado, enquanto as estratégias de proteção à vítima projetam efeitos para o futuro e exigem uma nova lógica de intervenção policial. Esse trabalho de proteção contra atos futuros não é apenas da Polícia Militar, responsável pelo policiamento preventivo, mas é igualmente da Polícia Civil, pois não é possível dissociar a intervenção investigativa da intervenção protetiva.

\footnotetext{
${ }^{14}$ Ver igualmente em Portugal o recente Manual do Policiamento de Violência Doméstica do MAI (PORTUGAL, 2014).

${ }^{15}$ Sobre o direito fundamental à segurança pública na atuação policial, ver ÁVILA, 2016a, p. 447.
} 
Um reflexão dessa visão de proteção pela polícia está delineada no art. 11 da Lei n. 11.340/2006, que descreve diversas atribuições protetivas que devem ser feitas pela "autoridade policial”, partindo da previsão genérica no inciso I (“garantir proteção policial”), passando pelas demais exemplificações de atuações protetivas, como transportar para a casa abrigo (inciso III), acompanhar a mulher na retirada de seus pertences no domicílio do casal (inciso IV), e ser ativa no fornecimento de informações à vítima sobre seus direitos e a rede de serviços (inciso V). Apesar das possíveis disputas dentro do campo policial por quem possui o título de "autoridade policial”, se apenas os delegados de polícia (conforme uma interpretação extensiva do art. $2^{\circ}$, $\S 2^{\circ}$, da Lei n. 12.830/2013 induziria) ou quaisquer policiais que venham exercer uma autoridade, inegavelmente também é responsabilidade da Polícia Civil zelar pela proteção à vítima.

Essa proteção transcende a mera informação sobre serviços disponíveis, conforme uma leitura superficial do art. 11, inciso V, da LMP poderia induzir, mas abrange uma verdadeira articulação entre a polícia e a rede de proteção de direitos, com uma postura ativa no compartilhamento de informações para a proteção. Na expressão de Pasinato (2015, p. 538):

Falta, nesse quesito, avançar na compressão de que essas mulheres não são apenas vítimas, mas pessoas cujas necessidades e dificuldades vão além dos episódios de violência, transbordando para outros campos onde as carências de direitos são, muitas vezes, a regra e não exceção.

Para se avançar na atuação preventiva em contexto de violência doméstica, é essencial que a polícia se abra para trabalhar em parcerias com outras instituições, a fim de fortalecer o diálogo interinstitucional, facilitando com que outras instituições compreendam as limitações da atuação policial, mas igualmente colaborem para o aperfeiçoamento possível da polícia, bem como que a polícia compreenda como funcionam outras instituições integrantes da rede de serviços e possa melhor se integrar nessa rede.

Nesse sentido, a CPMI da violência doméstica indicou a relevância da integração entre as delegacias de polícia especializadas e a rede local de enfrentamento à violência doméstica:

A articulação com a rede de serviços nem sempre acontece. Isto ocorre tanto em virtude da dispersão geográfica dos serviços e da falta de articulação entre eles quanto pela inexistência de uma rede institucionalizada, com reuniões regulares dos serviços e trocas de experiências entre os profissionais. (BRASIL, 2013, p. 50).

A perspectiva da atuação preventiva projeta a polícia para uma atuação proativa, não meramente reativa. Isso possibilita colocar a polícia como efetivo sujeito na efetivação das políticas de segurança pública em sentido mais amplo. Igualmente enseja a reorganização da política de segurança pública numa esfera transversal e interdisciplinar, já que compartilha as estratégias de 
proteção com outras instituições, como saúde, educação, assistência social, emprego e renda, justiça e outras. Essa visão de prevenção integrada passa pela consideração do enfrentamento à violência contra a mulher não apenas como um problema criminal, mas como um problema de políticas públicas, das quais as intervenções dos subsistemas policiais e de justiça são apenas uma das facetas (CAMPOS, 2017; PASINATO, 2010).

A atuação policial no contexto de violência doméstica deve ser, necessariamente, centrada nas necessidades da vítima (victim-centric policing). Segundo diretriz da Polícia de Victoria, Austrália, essa perspectiva de atuação policial deve estabelecer como prioridades (VICTORIA, 2015, p. 8):

a) Elevar o foco organizacional sobre as vítimas e pessoas que necessitam de auxílio;

b) Fornecer de forma tempestiva e adequada informações às vítimas;

c) Agilizar o processo de comunicação às instituições de apoio (referral) das vítimas e demais pessoas que necessitam de apoio;

d) Aumentar as oportunidades de empoderamento das vítimas.

Um dos indicadores de efetividade da atuação policial, no âmbito de Victoria, tem sido o incremento das comunicações (referrals) da polícia para os órgãos integrantes da rede, tanto das mulheres vítimas quanto de crianças expostas à situação de violência, de forma a assegurar a prevenção da reiteração da violência em razão de intervenções precoces no ciclo da violência (VICTORIA, 2016, p. 50).

Um exemplo de trabalho multiagência, ainda em Victoria, são os programas PACER e Alexis, em que um profissional da área de saúde mental realiza plantões em unidades policiais relacionadas à violência doméstica e realiza reuniões de coordenação periódicas, para auxiliar na atuação integrada entre atenção à saúde mental (da vítima ou do agressor) e enfrentamento da violência doméstica. No programa Alexis, também são realizadas visitas semanais à vítima para monitorar o respeito à medida protetiva, e para assegurar que a própria vítima não venha incentivar o contato com o agressor que constitua violação da ordem judicial (VICTORIA, 2016, p. 61-63).

A interação entre atividade policial e o fornecimento de informações à mulher sobre o trâmite processual tem sido indicada como promissora para diminuir a sua aflição aos rumos do processo e dar-lhe mais confiança para continuar colaborando com a persecução penal. Experiências no Brasil sinalizam ser promissora a integração de policiais no encaminhamento de mulheres para receberem acompanhamento especializado (ver o programa Portas Abertas, em Sobradinho/DF, em: SILVA; RIBEIRO, 2017, p. 204). Estudos indicam que a presença de um advocacy program para a vítima é uma das estratégias mais eficientes de elevar sua confiança no sistema e, assim, manter sua colaboração ao longo dos processos (BUZAWA; BUZAWA; STARK, 2017, p. 220; PATTERSON, 
2011). Esses programas deveriam ir além da atual atividade realizada pela Defensoria Pública, de apenas estar disponível para consultas por iniciativa da mulher, ou de acolhimentos psicossociais, para materializar-se em um processo de acompanhamento da vítima ao longo do processo, numa postura ativa de estar ao seu lado e prestando-lhe apoio antes, durante e depois dos atos processuais.

Uma das estratégias centrais para essa articulação, de forma a fomentar o compartilhamento de informações entre a instituição policial e a rede de parceiros, são as avaliações de risco. Estudos internacionais têm apontado que há um conjunto de fatores preditivos da maior probabilidade de ocorrência de novos episódios de violência doméstica de nível mais grave, potencialmente letal, a exigir um conjunto articulado de estratégias de intervenção em rede (ÁVILA, 2014; BUZAWA; BUZAWA; STARK, 2017, p. 395; CAMPBELL et al., 2003; MEDEIROS, 2015). Avaliação de risco e administração dos fatores de risco (planos de segurança) são estratégias centrais das políticas de prevenção criminal em contexto de violência doméstica. Elas permitem que os diversos integrantes da rede de serviços falem uma mesma linguagem sobre os riscos do caso concreto, e desperta na polícia o senso de que a integração no trabalho em rede também corresponde a uma atividade policial de proteção (MCCULLOCH, 2016, p. 35).

Para a efetividade dessa intervenção de gestão de riscos, é essencial que a Polícia Civil passe a realizar a avaliação de risco no momento do atendimento inicial à vítima e que os dados relevantes sejam efetivamente compartilhados com a rede de serviços em casos de risco elevado, mediante protocolos previamente estruturados. Também é essencial que haja, à proporção que as investigações avançam, uma atualização dinâmica da informação sobre os riscos.

Ainda que se reconheça que a polícia não possui expertise para realizar avaliações de risco em situações complexas, ou para realizar diretamente intervenções terapêuticas, deve haver uma maior capacitação dos policiais para realizarem avaliações de risco em situações ordinárias e para realizar os primeiros encaminhamentos de proteção, já que a polícia é usualmente uma das primeiras instituições a terem contato com as vítimas (MCCULLOCH, 2016, p. 44). E, como uma das consequências da perspectiva de gênero, não se pode desperdiçar as oportunidades de contato com a vítima.

Algumas experiências brasileiras já estão em andamento no sentido de introduzir rotinas de avaliação de risco quando do atendimento policial (ÁVILA, no prelo). Na implementação desse projeto, apesar de toda a sensibilidade da cúpula policial, percebeu-se a resistência de diversos policiais de ponta em se reconhecerem como corresponsáveis pelo preenchimento do formulário de avaliação de risco, como se o levantamento de tais informações sobre o histórico e o contexto da 
violência doméstica não fosse atribuição da Polícia Civil, mas de outras instituições. A participação desses policiais nas reuniões de rede foi decisiva para superar a resistência inicial.

É essencial que a Polícia Civil também se perspective como corresponsável pela proteção à mulher de atos futuros de violência. A intervenção protetiva é tão importante quanto a investigação criminal, não sendo legítimo que a necessária atividade de investigação drene todo os recursos institucional em detrimento das atividades de integração da intervenção policial na proteção à mulher. Conforme argumenta Campos (2017), é necessário um “novo giro paradigmático” na aplicação da Lei Maria da Penha, que privilegie as políticas de prevenção e assistência.

Dentro das políticas de gestão do risco, um dos caminhos essenciais é construir rotinas de construção de planos de segurança às vítimas, individualizados aos fatores de risco, fatores de proteção e fatores de diversidade específicos da vítima, bem como o seu monitoramento periódico (ASSOCIAÇÃO DE MULHERES CONTRA A VIOLÊNCIA, 2013).

Conforme argumenta Pasinato (2015), conceder as medidas protetivas de urgência sem articular um mecanismo de fiscalização significa apenas dar um pedaço de papel à vítima. Nesse sentido, afirmam Diniz e Gumieri (2016, p. 225), referindo-se a processos no Distrito Federal entre os anos de 2006 a 2012:

A pesquisa apresentou indícios da ausência de um sistema de monitoramento das medidas protetivas, que oriente as vítimas sobre como relatar casos de descumprimento, padronize as respostas judiciais a essas violações e garanta um acompanhamento ágil das medidas deferidas e vigentes, mesmo que em diferentes processos judiciais. Para responder a esses problemas, é necessário um esforço de diálogo entre as autoridades policiais, o Ministério Público e o Judiciário para o estabelecimento de um protocolo comum a ser implementado. As orientações desse protocolo para as vítimas poderiam ser veiculadas em materiais informativos, como as já mencionadas cartilhas sobre medidas protetivas.

Diversos estados têm criado programas específicos, no âmbito da Polícia Militar, para o monitoramento do cumprimento das medidas protetivas de urgência deferidas, com visitas periódicas às vítimas e aos agressores, como a Ronda Cidadã ou as Patrulhas Maria da Penha (GERHARD, 2014). No âmbito do Distrito Federal, tal programa é denominado de Prevenção Orientada à Violência Doméstica (PROVID). Como os recursos humanos dessas equipes são limitados, ordinariamente são selecionados apenas os casos de risco mais elevado para serem incluídos no monitoramento (ÁVILA, no prelo). Outras estratégias de monitoramento abrangem os dispositivos de socorro (em alguns locais, apelidados de "botão do pânico”16), eventualmente associados ao monitoramento por GPS do agressor (com tornozeleiras ou braceletes).

\footnotetext{
${ }^{16}$ Registre-se que essa nomenclatura "botão do pânico" acaba carregando forte ranço de revitimização, pois induz à representação de que seria necessário entrar em pânico para acionar o socorro policial, que a vítima deve carregar sempre
} 
O monitoramento dos casos de risco elevado constitui-se em verdadeira atividade de prevenção criminal, na perspectiva de vigilância de uma área sensível para a descoberta da notícia de crimes. Assim, a posterior atividade de investigação se converte em uma progressão da anterior atividade de vigilância de condutas habituais ${ }^{17}$. As visitas de monitoramento de medidas protetivas de urgência visam tanto dissuadir a prática de novas violências à mulher, quanto detectar sua prática e recolher as informações necessárias para permitir sua responsabilização. Há um caráter unitário e indivisível nessa função. Nas palavras de Valente (2009, p. 43): “a atividade jurídico-administrativa e jurídico-criminal de uma polícia pós-moderna se deve basear em primeira linha na prevenção do perigo - que antecede à prevenção do dano”.

Não se desconhece o risco de que uma expansão desenfreada da atividade de prevenção venha gerar uma nova tecnologia de controle social, um novo panoptismo (cf. ALBRECHT, 1989, p. 47; HASSEMER, 1999, p. 261), a recair preferencialmente sobre os grupos sociais mais vulneráveis - no contexto brasileiro, os negros e pobres. Todavia, a legitimidade da intervenção policial de monitoramento das medidas protetivas de urgência decorre de uma demanda anterior de proteção por parte da vítima, do risco objetivo por esta experimentado, e do elevado valor do direito fundamental à proteção da vítima, decorrente das inúmeras pesquisas que documentam o risco concreto à sua vida no contexto de violência doméstica (cf. por todos CAMPBELL et al., 2003). Eventuais ingerências na esfera de direitos do investigado, como o monitoramento eletrônico, deverão estar amparadas por prévia decisão judicial, com o devido recurso ao princípio da proporcionalidade para justificar a excepcional restrição de direitos fundamentais diante do grave quadro de risco à vítima.

Finalmente, a participação de policiais de referência, especializados no enfrentamento à violência doméstica, em comissões locais de enfrentamento à violência doméstica e de articulação do trabalho de rede deve ser institucionalmente vista como uma atividade funcional. É necessário criar mecanismos para se mensurar essa participação, dando-se visibilidade estatística ao trabalho de articulação de rede na esfera policial. Um dos aspectos relevantes nessa integração é assegurar que não haja uma excessiva rotatividade na lotação dos policiais nessas unidades especializadas, de forma a não se perder as relações de confiança com as vítimas e integrantes da rede que são construídas nessa função (VICTORIA, 2016, p. 78).

\footnotetext{
o dispositivo consigo, pois o estado de pânico é iminente. Outras nomenclaturas menos revitimizantes poderiam ser utilizadas (como “botão de socorro”, “ajuda”, “emergência” ou “proteção”).

17 Sobre a possibilidade de a atividade de investigação criminal se tornar uma progressão da atividade de polícia administrativa, cf. ÁVILA, 2016a, p. 49.
} 
Uma das novas fronteiras para se avançar na atividade de prevenção são os comitês de rede para a gestão de casos de elevado risco (ÁVILA, no prelo). Tais comitês deveriam não apenas discutir genericamente protocolos de cooperação interagências, mas especialmente ter uma rotina de discussão de casos concretos de risco elevado, de forma a procedimentalizar uma rotina de cooperação interinstitucional de gestão de risco em contexto de crise.

\section{CONCLUSÃO}

O presente trabalho sustenta que a incorporação da perspectiva de gênero no âmbito da atuação policial impõe uma reformulação da intervenção tradicional, de forma a abranger o acolhimento das vítimas como estratégia de eficiência da atividade policial de investigação e de proteção, a necessidade de reformulação da investigação criminal para incorporar outros elementos de prova além da palavra da vítima, e a integração da polícia na articulação do trabalho em rede como mecanismo de promoção da proteção das vítimas.

Usualmente, a superação desses desafios passa pelo investimento em protocolos de atuação, treinamento, supervisão, avaliação da implementação das diretrizes, e reformulação das diretrizes (ÁVILA, 2016a, p. 397-408), especificamente focados nas peculiaridades dessa criminalidade sob a perspectiva de gênero. Sobretudo, passa por uma reforma na cultura organizacional policial relacionada aos valores de equidade de gênero e valorização da mulher dentro das próprias instituições policiais (VICTORIA, 2016, p. 31), e pela reformulação da visão estratégica das organizações policiais para se perspectivarem como responsáveis pela proteção integral às vítimas.

Uma parcela dos problemas estruturais da investigação criminal não pode ser inteiramente solucionada no âmbito do subsistema de violência doméstica contra a mulher, diante das limitações estruturais, especialmente a não responsabilidade pela Polícia Militar da investigação criminal no momento do atendimento da ocorrência e o caráter burocrático e hermético do inquérito policial. Todavia, o subsistema da Lei Maria da Penha tem permitido alguns “lampejos de racionalidade” na interação dos órgãos dos sistemas policial e de justiça, com experiências embrionárias de integração em rede e intervenção orientada à solução de problemas. Essa perspectiva da atuação em rede permite problematizar, inclusive, a atual centralidade da Delegacia de Polícia como porta do sistema de proteção, em favor de um novo sistema de múltiplas portas que não seja centrado apenas na criminalização, mas especialmente na proteção.

Além das reformas no âmbito das instituições policiais, é necessário agregar os demais interlocutores para a discussão das políticas de segurança pública de proteção às mulheres. Entre os 
participantes desse controle democrático da atuação policial estão o Ministério Público, enquanto órgão de controle externo da polícia e de promoção de proteção dos direitos fundamentais das vítimas (ÁVILA, 2016a), os movimentos de mulheres e feministas, bem como os núcleos acadêmicos de pesquisas de gênero e de segurança pública. Uma adequada incorporação da perspectiva de gênero nas políticas de segurança pública pode dar a esperança de melhores dias às mulheres brasileiras.

\section{REFERÊNCIAS}

ADORNO, Sérgio; PASINATO, Wânia. Crime, violência e impunidade. Revista eletrônica de jornalismo científico, n. 98, 10 maio 2008. Disponível em: <https://goo.gl/AvK1dU>. Acesso em: 22 mar. 2017.

ALBRECHT, Peter-Alexis. Prevention as a problematic objetive in the criminal justice system. In: ALBRECHT, Peter-Alexis; BACKES, Otto. Crime prevention and intervention: legal and ethical problems. Berlim: Walter de Gruyter, 1989, p. 47-72.

ANDRADE, Vera Regina Pereira. Criminologia e feminismo: da mulher como vítima à mulher como sujeito de direito. In: CAMPOS, Carmen Hein de (Org.). Criminologia e feminismo. Porto Alegre: Sulina, 1999, p. 105-117.

ANGELIM, Fábio Pereira. A importância da intervenção multidisciplinar face à complexidade da violência doméstica. In: LIMA, Fausto Rodrigues de; SANTOS, Claudiene (Org.). Violência doméstica: vulnerabilidades e desafios na intervenção criminal e multidisciplinar. Rio de Janeiro: Lumen Juris, 2009, p. 125-136.

ASSOCIAÇÃO DE MULHERES CONTRA A VIOLÊNCIA (AMCV). Avaliação e gestão de risco em rede: manual para profissionais. Lisboa: AMCV, 2013. Disponível em: <https://goo.gl/A5nrE6>. Acesso em: 31 mar. 2017.

ÁVILA, Thiago André Pierobom de. Articulação do trabalho em rede para a proteção à mulher em situação de violência doméstica e familiar. Revista do CNMP. No prelo.

ÁVILA, Thiago André Pierobom de. Fundamentos do controle externo da atividade policial. Belo Horizonte: D’Plácido, 2016a.

ÁVILA, Thiago André Pierobom de. Investigação criminal: o controle externo de direção mediata pelo Ministério Público. Curitiba: Juruá, 2016b.

ÁVILA, Thiago André Pierobom de. O sistema francês. In: ÁVILA, Thiago André Pierobom de. (Org.). Modelos europeus de enfrentamento à violência de gênero: experiências e representações sociais. Brasília: ESMPU, 2014, p. 203-299.

BANDEIRA, Lourdes Maria; THURLER, Ana Liési. A vulnerabilidade da mulher à violência doméstica: aspectos históricos e sociológicos. In: LIMA, Fausto Rodrigues de; SANTOS, Claudiene 
(Org.). Violência Doméstica: vulnerabilidades e desafios na intervenção criminal e multidisciplinar. Rio de Janeiro: Lumen Juris, 2009, p. 159-167.

BRASIL. Diretrizes nacionais de investigação criminal com perspectiva de gênero. Brasília: Secretaria de Políticas para Mulheres da Presidência da República, Senasp/MJ, Copevid, 2016.

BRASIL. Informações da Central do Ligue 180 fornecidas com amparo na Lei de Acesso à Informação. Brasília: SPM, 2017 [e-mail encaminhado ao autor em 11 abr. 2017].

BRASIL. Relatório final da Comissão Parlamentar Mista de Inquérito (CPMI) criada com a finalidade de investigar a situação da violência contra a mulher no Brasil. Brasília: Senado Federal, 2013. Disponível em: <https://goo.gl/9dFQzL>. Acesso em: 27 mar. 2017.

BUZAWA, Eve S.; BUZAWA, Carl G.; STARK, Evan D. Responding to domestic violence: The integration of criminal justice and human services. 5. ed. Los Angeles: SAGE, 2017.

CAMPBELL, Jacquelyn et al. Risk factors for femicide in abuse relationships: Results of a multisite case control study. American Journal of Public Health, n. 93(7), p. 1.089-1.097, 2003.

CAMPOS, Carmen Hein de. Lei Maria da Penha: necessidade de um novo giro paradigmático. Revista Brasileira de Segurança Pública, São Paulo, v. 11, n. 1, p. 10-22, fev.-mar. 2017.

CAMPOS, Carmen Hein de; CARVALHO, Salo de. Violência doméstica e Juizados Especiais Criminais: análise a partir do feminismo e do garantismo. Estudos feministas, Florianópolis, 14(2), p. 409-422, maio-ago. 2006.

CARNEIRO, Suelaine. Mulheres negras e violência doméstica: decodificando os números. São Paulo: Geledés, 2017.

CARVALHO, José Raimundo; OLIVEIRA, Victor Hugo. Pesquisa de condições socioeconômicas e violência doméstica e familiar contra a mulher: prevalência da violência doméstica e impacto nas novas gerações. 2016. Disponível em: <https://goo.gl/bzEFGB>. Acesso em: 4 abr. 2017.

CUSSEN, Tracy; BRYANT, Willow. Domestic/family violence in Australia. Research in Practice, 38, 2015.

DATASENADO. Relatório de Pesquisa: violência doméstica contra a mulher. Brasília: Senado, 2005. Disponível em: <https://goo.gl/MFAfQC>. Acesso em: 4 abr. 2017.

DATASENADO. Violência doméstica e familiar contra a mulher. Brasília: Senado, 2013. Disponível em: <https://goo.gl/AHRHsc>. Acesso em: 4 abr. 2017.

DATASENADO. Violência doméstica e familiar contra a mulher: pesquisa de opinião pública nacional. Brasília: Senado, 2011. Disponível em: <https://goo.gl/PzjeUP>. Acesso em: 4 abr. 2017.

DINIZ, Debora; GUMIERI, Sinara. Implementação de medidas protetivas da Lei Maria da Penha no Distrito Federal entre 2006 e 2012. Pensando a segurança pública, v. 6 (direitos humanos, grupos vulneráveis e segurança pública). Brasília: MJ, p. 205-231, 2016. 
DISTRITO FEDERAL. Relatório Estatístico do MPDFT referente à violência doméstica contra a mulher no Distrito Federal no período de 2006 a 2016. Brasília: MPDFT, 2017. Disponível em: <https://goo.gl/A628oo>. Acesso em: 27 mar. 2017.

EIGENBERG, Helen M.; KAPPELER, Victor E.; MCGUFFEE, Karen. Confronting the complexities of domestic violence: A social prescription for rethinking police training. Journal of Police Crisis Negotiations, n. 12(2), p. 122-145, 2012.

FÓRUM BRASILEIRO DE SEGURANÇA PÚBLICA (FBSP). Anuário Brasileiro de Segurança Pública 2015. 2015. Disponível em: <https://goo.gl/za9CFQ>. Acesso em: 4 abr. 2017.

FUNDAÇÃO PERSEU ABRAMO (FPA). Violência doméstica. São Paulo: FPA, 2011. Disponível em: <https://goo.gl/Eg7QGu>. Acesso em: 4 abr. 2017.

GERHARD, Nádia. Patrulha Maria da Penha: o impacto da ação da polícia militar no enfrentamento da violência doméstica. Porto Alegre: EDIPUCRS, 2014.

GOMES, Ana Paula Portella Ferreira. Como morre uma mulher? Configurações da violência letal contra mulheres em Pernambuco. 2014. 394 f. Tese (Doutorado em Sociologia) - Universidade Federal de Pernambuco, Recife, 2014. Disponível em: <https://goo.gl/EiC9ZX>. Acesso em: 4 abr. 2017.

HASSEMER, Winfried. La Policía en el Estado de Derecho. In: HASSEMER, Winfried. Persona, mundo y responsabilidad: bases para una teoría de la imputación en derecho penal. Tradução Francisco Muñoz Conde e María del Mar Díaz Pita. Valência: Tirant lo Blanc, 1999, p. 249-294.

HIRSCHEL, David J.; BUZAWA, Eve S. The role and impact of primary aggressor laws and policies. Journal of Police Crisis Negotiations, n. 12(2), p. 165-182, 2012.

INSTITUTO BRASILEIRO DE GEOGRAFIA E ESTATÍSTICA (IBGE). Censo Demográfico 2010: características gerais da população, religião e pessoas com deficiência. Brasília: IBGE, 2010. Disponível em: <https://goo.gl/P5Xp8F>. Acesso em: 4 abr. 2017.

KALKMANN, Suzana et al. Racismo institucional: um desafio para a equidade no SUS? Saúde e Sociedade, São Paulo, v. 16, n. 2, p. 146-155, 2007.

KLEIN, A. R. Practical implications of current domestic violence research: For law enforcement, prosecutors and judges. Washington, DC: National Institute of Justice, 2009.

MACHADO, Lia Zanotta. Onde não há igualdade. In: MORAES, Aparecida; SORJ, Bila (Org.). Gênero, violência e direitos na sociedade brasileira. v. 1. Rio de Janeiro: 7 Letras, 2009, p. 158183.

MCCULLOCH, Jude et al. Review of the family violence risk assessment and risk management framework (CRAF): final report. Melbourne: Monash University, 2016. 
MEDEIROS, Marcela Novais. Avaliação de risco em casos de violência contra a mulher perpetrada por parceiro íntimo. 2015. 235 f. Tese (Doutorado em Psicologia Clínica e Cultura) Universidade de Brasília (UnB), Brasília, 2015.

MISSE, Michel (Org.). O inquérito policial no Brasil: uma pesquisa empírica. Rio de Janeiro: Booklink, 2010.

NAVARRO-SWAIN, Tania. Entre a vida e a morte, o sexo. In: NAVARRO-SWAIN, Tania; STEVENS, Cristina (Org.). A construção dos corpos: perspectivas feministas. Ilha de Santa Catarina, SC: Editora Mulheres, 2008, p. 285- 302.

ONU MULHERES. Diretrizes nacionais feminicídio: investigar, processar e julgar com perspectiva de gênero as mortes violentas de mulheres. Brasília: ONU, SPM/PR e Senasp/MJ, 2016.

OUR WATCH; AUSTRALIA'S NATIONAL RESEARCH ORGANISATION FOR WOMEN'S SAFETY (ANROWS); VICHEALTH. Change the story: a shared framework for the primary prevention of violence against women and their children in Australia. Melbourne: Our Watch, 2015.

PASINATO, Wânia. Acesso à justiça e violência contra a mulher em Belo Horizonte. São Paulo: Annablume/FAPESP, 2012.

PASINATO, Wânia. Acesso à justiça e violência doméstica e familiar contra as mulheres: as percepções dos operadores jurídicos e os limites de aplicação da Lei Maria da Penha. Revista Direito GV, São Paulo, n. 11(2), p. 407-428, jul.-dez. 2015.

PASINATO, Wânia. Lei Maria da Penha: novas abordagens sobre velhas propostas: onde avançamos? Civitas, 10(2), p. 216-232, 2010.

PATTERSON, Debra. The linkage between secondary victimization by law enforcement and rape cases outcomes. Journal of Interpersonal Violence, n. 26(2), p. 328-347, 2011.

PORTUGAL. Manual do policiamento de violência doméstica. Lisboa: MAI, 2014.

RAMOS, Silvia; MUSUMECI, Leonarda. Elemento suspeito: Abordagem policial e discriminação na cidade do Rio de Janeiro. Rio de Janeiro: Civilização Brasileira e CESeC, 2005.

SAMPAIO, Elias de Oliveira. Racismo institucional: desenvolvimento social e políticas públicas de caráter afirmativo no Brasil. Revista Internacional de Desenvolvimento Local, v. 4, n. 6, p. 77-83, mar. 2003.

SILVA, Danielle Martins; RIBEIRO, Diogo Abe. Função orientadora das Corregedorias do Ministério Público na promoção da igualdade de gênero. Revista Jurídica Corregedoria Nacional: a atuação orientadora das Corregedorias do Ministério Público, v. 2. Brasília: CNMP, p. 187-216, 2017.

SOARES, Luiz Eduardo; BALESTRERI, Ricardo. A raiz de nossos problemas de segurança. Folha de São Paulo, 18 maio 2012. 
SUXBERGER, Antonio Henrique Graciano. O sistema inglês. In: ÁVILA, Thiago André Pierobom de (Org.). Modelos europeus de enfrentamento à violência de gênero: experiências e representações sociais. Brasília: ESMPU, 2014, p. 301-383.

VALENTE, Manuel Monteiro Guedes. Teoria geral do direito policial. 2. ed. Coimbra: Almedina, 2009.

VICTORIA. Future directions for victim-centric policing. Melbourne: Victoria Police, 2015.

VICTORIA. Royal Commission on Family Violence: Report and recommendations. V. 3. Melbourne: RCFV, 2016. Disponível em: <https://goo.gl/bimKBc>. Acesso em: 4 abr. 2017.

WAISELFISZ, Julio J. Mapa da Violência 2015: Homicídios de mulheres no Brasil. Brasília: Flacso, 2015.

WALKER, Lenore E. The Battered Woman. Nova Iorque: Harper and Row, 1979.

WHITE, Michael D. Police officer body-worn cameras: assessing the evidence. Washington, DC: Office of Justice Programs Diagnostic Centre, 2014.

Thiago André Pierobom de Ávila Pós-Doutor em Criminologia pela Monash University (Austrália). Doutor em Ciências Jurídico-Criminais pela Universidade de Lisboa. Mestre em Direito Público pela Universidade de Brasília. Pesquisador Associado ao Instituto de Direito Penal e Ciências Criminais da Universidade de Lisboa. Fellow in the research program on gender and family violence, new frameworks on prevention - Monash University. Promotor de Justiça no Ministério Público do Distrito Federal e Territórios. E-mail: thiago.pierobom@hotmail.com 